\title{
Peer to Peer Lending Industry in China and Its Implication on Economic Indicators: Testing the Mediating Impact of SMEs Performance
}

\author{
Babak Naysary $^{1} \&$ Siti Nurbaayah Daud ${ }^{1}$ \\ ${ }^{1}$ Faculty of Business, Communication and Law, INTI International University, Nilai, Malaysia \\ Correspondence: Babak Naysary, Faculty of Business, Communication and Law, INTI International University, Nilai, \\ Malaysia. Tel: 60-11-1289-0231.
}

Received: September 27, 2020

Accepted: November 11, 2020

Online Published: January 11, 2021

doi:10.5430/ijfr.v12n2p106

URL: https://doi.org/10.5430/ijfr.v12n2p106

\begin{abstract}
This papers studies and analyses the development and current status of Financial Technology (FinTech) industry and Peer-to-Peer (P2P) Lending industry in the People's Republic of China (mainland China), and then investigates the impact of the P2P industry on development of Chinese Small and Medium-sized Enterprises (SMEs) as well as selected economic indicators. Due to the fact that Fintech and more particularly P2P industry is a recent phenomenon, secondary data was collected for 2014 to 2019 from government data sources and company's websites. The results of Structural Equation Modeling (SEM) analysis indicate the significant impact of P2P lending industry on the economic indicators with mediating impact of SMEs performance. The finding shed light on the financing difficulties faced by SMEs and the role of P2P industry to bridge this gap which have implications for government policies and financial institutions.
\end{abstract}

Keywords: fintech, P2P lending, SMEs, China economic indicators, SEM

\section{Introduction}

Despite various definitions of Fintech extant in the literature, the term FinTech refers to online platforms that combine financial services with extensive use of technology in their operations (Susilo et al., 2019). Compared to conventional financial services, FinTechs are all Internet-based tools, platforms or applications which provide variety of services from online payments, lending, capital financing to Robo-advisors and assets management (Arner et al., 2016). With the help of FinTech, investors and borrowers previously rejected by the financial industry can now access the market which helps to promote economic development and poverty reduction (Bruhn and Love, 2014). For SMEs, FinTech's new platform provides them with a wide range of alternative financing methods and services, with low-cost that can meet their neglected requirements in the current market (Hinson, et al., 2019).

According to national statistics in 2013, there are more than 15 million enterprises in China, of which more than 11 million are small and micro enterprises, accounting for $94 \%$ (Ma, et al., 2019). SMEs are facing great difficulties, which is a common consensus now. As the operating costs and production costs of Chinese companies have risen significantly, many manufacturing industries have also relocated from China (Wang, 2020). Coupled with China's transformation and upgrading strategy in recent years, and the lack of necessary conditions and capabilities of SMEs, it has led to the bankruptcy and accelerated transformation of SMEs. Nevertheless, according to data from the Statista Research Department, the number of SMEs in China has increased from about 10 million (2010) to 38.82 million (2019), and it is expected that there will be 43.03 million in 2020 (Ju, et al., 2019). Data from the 5th Annual Meeting of China Microfinance Institutions show that about 4 million small and medium-sized enterprises in China need financial support but do not receive financing (Dai, 2017). This phenomenon seriously restricts the performance of SMEs.

The difficulty of financing SMEs has been a major problem in China for decades, but there is still no effective solution. Inclusive finance has been proposed in China for a long time, but solving the problem of financing difficulties for SMEs has not achieved the expected results (Wang, 2018). However, with the development of internet finance and FinTech in the past decade, it seems that there are new solutions to the financing difficulties of SMEs, such as P2P lending, crowdfunding, and big data venture capital. Recently, P2P lending industry has emerged as financial innovation and has been widely accepted by financial markets worldwide and in the meantime China has been in the forefront of developments (Shim and Shin, 2016). During 6 years from 2010 to 2015, China's P2P 
lending industry led the world, increasing the number of platforms from 15 to just under 4,000 (Hung, 2019). The ability to link private capital to specific cash needs is considered a powerful force in solving many financial problems especially for SMEs.

Given the significant role of SMEs in China's economy and considering their financing difficulties through conventional channels, this research attempts to investigate the impact of SMEs on the economic performance in the last 6 years (from 2014 to 2019) while examining the mediating role of Fintech financing instruments. The results could in one hand shed light on the compelling role of Fintech in the already revolutionized financial markets, urging more scrutiny on its manifold implications in various economic sectors; and on the other hand draw attention to the economic units which are deprived from accessing their required funds, which requires government and financial regulators to consider alternative solutions to address this issue. From a theoretical perspective, this research contributes to the literature as one of the first attempts to test the mediating role of Fintech, more particularly P2P lending industry, on the economic performance in light of Transaction cost theory.

\section{Literature Review}

\subsection{FinTech}

With the popularity of the Internet in the early 1990s, the term FinTech was proposed when electronic payments, ATMs, and online banking were promoted globally by financial institutions (Arner, et al., 2016; Lee and Shin, 2018). After the global financial crisis in 2008, FinTech has entered a new stage. According to data from PwC's DeNovo platform, FinTech has grown at an annual rate of approximately $41 \%$ over the past four years, with a cumulative investment of more than $\$ 40$ billion. In the United States, investment in the FinTech industry has grown to \$ 19 billion (2015) from $\$ 1.8$ billion (2010), which has shown exponential growth (Citi Group, 2016), and up to 82\% of companies have indicated that they are willing to increase their cooperation with FinTech shortly (Crosswell and Estlin, 2019). In Britain, there are already over 1,600 FinTech companies, and they may double in 10 years. Similarly, more than $4 / 5$ of UK companies have stated that they will cooperate with FinTech soon (Crosswell and Estlin, 2019).

However, the FinTech industry is also facing some problems. At present, FinTech is still in its infancy or primary stage in many countries. Government regulations and laws in many regions have not classified the word FinTech. Therefore, the legal obligations and responsibilities of FinTech companies are similar to traditional offline services. The ratio is also very different. Half of the respondents believe that new business models are facing regulatory obstacles to innovation (PWC, 2017). In 2019, due to China's promotion of 5G in various regions, more and more Chinese financial platforms favor advanced technologies that are ahead of the world, such as big data, 5G networks, cloud computing, blockchain and artificial intelligence.

\subsection{The Development of P2P Lending}

P2P lending is loan-based lending with numerous similarities with crowdfunding (Mamonov and Malaga, 2018). Because P2P lending can quickly resolve customers' short-term funding shortages without the need for banks' complicated loan terms and long-term review requirements, P2P lending platforms have become an important source of funding for most Chinese SMEs and individual consumers without a credit history (Suryono, et al., 2019). On the P2P lending platform, businesses or individuals can access the market for mutual investment and borrowing (Suryono, et al., 2019) but this will have some credit and regulatory problems, especially in countries and regions with underdeveloped legal system.

Although compared with the simple, fast and low-cost model of P2P lending, bank loans do have a lot of shortcomings; however, banks have more stable sources of funds, large loan funds and other banking services (Welltrado, 2018). Therefore, companies still prefer to choose regular banks and other financial institutions as long-term borrowing targets. However, changes in accounting standards in the United States show that P2P lending has become a substitute for bank loans in some markets, and it mainly serves SMEs and individuals that are ignored by banks.

The scale of credit market development is directly proportional to the local average income level and inversely proportional to banking competition and financial regulation (Claessens et al., 2018). This can support the rapid growth of FinTech and credit markets in the UK, US and China. However, since 2018, restrictions on crowdfunding and P2P industries in China's local government, and forced closures of unqualified companies have led to a sharp decline in global investment in fintech companies.

As of the end of December 2019, the number of platforms in China's P2P lending industry operating normally dropped to 343. In 2019, the transaction volume of China's online loan industry reached RMB 96.411 billion, which 
was a decrease of $46.24 \%$ compared to the full-year online loan transaction volume in 2018 (RMB 17.94801 billion). The full-year volume in 2019 reached a new low of nearly five years (WDZJ, 2019). Wang Jingwu, director of the Financial Stability Bureau of the Central Bank of China, said that P2P lending platforms have been reduced by more than 4,000, 173 virtual currency trading platforms have all been withdrawn, and equity crowdfunding and Internet insurance have been completed (Wang, 2020). However, these restrictions on P2P lending platforms, does not mean that this industry will disappear in China (Liu, et al., 2019). Xu (2019), Moody's Investors Service, said that Since 2018, financial regulators across China have severely cracked down on crimes in the P2P industry and encouraged state-owned banks to do their best to support SMEs. But poorly funded SMEs still have difficulty obtaining funds from banks and securities markets.

\subsection{SMEs Financing Issues}

In 1979, China began its economic transformation and financial modernization. However, since then, China's credit market has been affected by inefficient allocations, especially by SMEs. Bailey et al. (2011) calculated in 2007 that only $1.3 \%$ of loans provided by Chinese state-owned banks went to private companies. SMEs account for $80 \%$ of the country's economic output, and only $20 \%$ of credits issued by banks are for SMEs, especially start-ups, and it is difficult to obtain financing from traditional banking markets (Shim \& Shin, 2016). Because large state-owned banks do not provide loans to SMEs (Zhang, 2002; Bailey, Huang, \& Yang, 2011; Lin \& Chen, 2012), while small banks focus on specific areas and wealthy customers (Tanaka \& Molnar, 2008; Zhang, et al., 2013). World Bank (2013) estimates that only 25\% of SMEs in China received bank credit from 2011 to 2013. McKinsey \& Company data shows that family businesses and SMEs contribute 70\% to 90\% of global GDP (McKinsey, 2014). In 2015, more than 20 million SMEs were registered in China, providing more than $80 \%$ of urban employment opportunities. These formal SMEs earn $64.5 \%$ of the total profits of all industrial enterprises and contribute $49.2 \%$ of fiscal and tax revenue (MIIT, 2016). Economists have long criticized China's state-owned banking system for giving too many loans to large state-owned enterprises, even though SMEs account for $60 \%$ of China's GDP and create $75 \%$ of new jobs (Shim \& Shin, 2016).

In November 2015, the transaction volume of P2P financing platforms reached 3.782 billion yuan, an increase of $6.46 \%$ from the previous quarter. The average interest rate is $11.51 \%$, and the average borrowing period is 6.61 months. On P2P online loan platforms, more than half of the funders are SMEs (Xue and Shui, 2015). This means that more and more companies will choose P2P online loan as a new channel when financing.

In 2015, the average lending rate of P2P online lending platforms was about 18\% (Chen \& Ye, 2016), and for small and medium-sized enterprises with relatively good credit, the bank lending rate was usually $8.34 \%$. However, not all SMEs can enjoy this seemingly low-interest rate on bank loans. Because banks require SMEs to submit a deposit, between $10 \%$ and $20 \%$ of the loan value, in an escrow account, which means that only $80 \%$ to $90 \%$ of the loans are actually visits to SMEs although the entire loan amount must pay interest (Ba, 2013). In fact, if financial guarantee companies charge additional fees, such as loan consulting fees and or loan evaluation fees, the total borrowing cost of bank loans may be higher. So, many SMEs have to rely on interest rates from other sources of funding. For example, sometimes SMEs have to pay very high-interest rates, ranging from $36 \%$ to $60 \%$, to borrow money from state-owned enterprises, and state-owned enterprises can obtain loans from the banking system (Huang, 2017).

According to the World Bank's "Emerging Market SMEs Financing Gap" report in 2018, China has the largest number of SMEs in the world. Its potential financing demand is as high as USD \$ 4.4 trillion, while the current financing supply for small, medium and micro enterprises is only USD \$ 2.5 trillion, and the financing gap is as high as US \$ 1.9 trillion (Yang, 2019).

\subsection{SMEs Financing and P2P Lending}

From the perspective of credit allocation, Bechtti, et al., (2008), Zhao (2014), Yu and Xie (2014) and others pointed out the positive significance of P2P for SMEs financing through theoretical analysis. Degryse and Cayseele (2000) used European SMEs data to find that non-bank lending has greatly supported SMEs financing and that in regions with many SMEs, there are also many loan channels. Li Zhaohui (2015) found similar rules using empirical analysis using Chinese P2P industry data and SMEs statistical yearbook data. In regions with many SMEs, there are also many P2P network platforms. After several years of development, some P2P financial companies using this business model have turned their target borrowers into enterprises, so they call themselves P2B (Peer to Business) financial companies (Moreno, 2019). Therefore, these companies need a larger and more professional risk control management team to ensure that borrowers can pay their debts, which makes them larger than other companies. Some P2P financing companies in China have now converted to pure P2B financing, which means they only accept corporate loan requests. For example, Guan Yitong, Xinhehui and PPmoney. These results are confirmed in a recent 
study by Rosavina et al. (2019) introducing P2P lending as an alternative financing method which is considered by SMEs to obtain their loans. Their study has been conducted using semi-structured interviews and identified the root causes of SMEs tendency to turn to P2P lenders to be loan process and documentations, interest rates, processing costs, loan amount and finally loan flexibility.

In summary, despite the issues and problems surrounding P2P industry in China, this industry is currently the easiest way to solve the financing problem of SMEs. However, this method should be able to solve the problem directly, rather than transferring the problem.

\subsection{Transaction Cost Theory}

The British economist Ronald Coase first proposed the theory in 1937 (Coase, 1993). This theory shows that transaction costs exist in any economic activity, and people will consider the cost of transaction in the process of economic activities to determine economic decisions.

Transaction cost theory explains why traditional financial institutions such as banks are reluctant to provide loans to SMEs. This is to reduce the risk of loans, banks have estimated transaction costs such as management costs, time costs, transaction costs, information costs, contract costs, credit evaluation costs, risk control costs, and bad debt costs for individual businesses when conducting loan reviews. This has led to the conclusion that the loan to SMEs had a high rate of bad debts and losses. That means, if banks lend money to SMEs, they will face a greater default risk.

In terms of the P2P lending platform, its credit rating system can improve the financing efficiency of SMEs and reduce short-term borrowing costs (Wang and Liao, 2014). Because the P2P platform does not require the complicated review of the bank's loan system, the borrowers are classified and reviewed only through the credit rating system. This greatly reduces the cost of bids and time, which is very beneficial for SMEs that urgently need short-term funding. Transaction cost theory can well explain that P2P lending can effectively support SMEs to solve short-term funding needs.

In light of the concepts highlighted in the literature review, supported by the transaction cost theory, the following hypotheses are developed in this paper:

H1: Development of P2P Lending Industry has a positive significant relationship with Performance of Chinese SMEs

H2: Performance of SMEs has a positive significant relationship with Economic indicators in China.

H3: Development of P2P lending industry has a positive significant relationship with Economic indicators in China.

\section{Methodology and Measurement}

\subsection{Data Collection and the Sample}

The research objects of this study are the Chinese P2P industry and SMEs. The units of analysis are the top 100 SMEs in Information Technology industry. Secondary data has been collected from the companies' websites, government data sources (National Bureau of Statistics of China) and third party online data sources. Due to the fact that Fintech and more particularly P2P industry is a recent phenomenon, secondary data was collected for the period 2014 to 2019.

\subsection{Definitions and Measurements of Variables}

The objective of this paper is to investigate the impact of developments in P2P lending industry and SMEs performance on the China's economy. For the purpose of measuring the independent variable, factors such as number of P2P lending, number of platforms in operation, volume of business turnover, net capital inflow, average duration of loan, number of investors, number of borrowers, amount of investment per capita and amount of borrowing per capita have been chosen as indicators of developments in P2P lending industry. As for the mediating variable, number of SMEs in China, total revenue, net income, total assets, total liabilities and total equity of 100 sample SMEs firms has been chose as indicators. And finally, annual average inflation rate, urban registered unemployment rate, GDP (Gross Domestic Product) and total tax were used as economic indicators.

\subsection{Data Analysis}

In order to test the hypothesized paths, this research employed structural equation modeling (SEM) with measurement error terms specified. Using AMOS 24.0 with maximum likelihood estimation allowing simultaneous estimation of the projected paths, the relationships were tested by entering the correlation matrix into the program. Validity of the measurement model was tested using confirmatory factor analysis (CFA) and reliability was checked by using Cronbach's $\alpha$ coefficient. 


\section{Empirical Results}

This paper uses SEM to verify the research hypotheses. SEM is a statistical technique for testing and estimating causal relationships in a more powerful way. In addition, SEM includes two levels of analysis - the measurement model and the structure model. The measurement model verifies how hypothetical constructs are measured in terms of the observed variables and the structural model examines the relationships among the constructs (Anderson and Gerbing 1988).

\subsection{The Results of the Measurement Model}

Table 1 presents the correlations among the research constructs. As can be seen in Table 1, there are positive correlations between the research constructs: P2P lending industry, SMEs performance and economic indicators.

Table 1. Correlations of the constructs

\begin{tabular}{lll}
\hline Constructs & 1 & 2 \\
\hline 1. P2P lending industry & & \\
\hline 2. SMEs performance & $0.457 *$ & \\
\hline 3. Economic indicators & $0.385 * *$ & $0.532 * *$ \\
\hline
\end{tabular}

Note: $* \mathrm{p}<0.05, * * \mathrm{p}<0.01$

In order to check the validity and reliability of the measurement model, CFA has been used in this research, the results of which are presented in Table 2. As we can see in Table 2 all three constructs in the study can be categorized into one factor. According to the results of CFA, the model fit of the measurement model is within the acceptable range $\left(\chi^{2}=\right.$ 194.168, $\mathrm{df}=96, \mathrm{CFI}=0.881$, IFI $=0,91, \mathrm{RMSEA}=0.086$ ).

Table 2. Factor analysis results

\begin{tabular}{llll}
\hline Constructs & Number of items & Number of factors & $\begin{array}{l}\text { Accumulation percentage of } \\
\text { explained variance }(\%)\end{array}$ \\
\hline P2P lending industry & 8 & 1 & 69.745 \\
\hline SMEs performance & 6 & 1 & 78.364 \\
\hline Economic indicators & 4 & 1 & 81.872 \\
\hline
\end{tabular}

One of the measures to examine the reliability of the measurements in by computing the Cronbach's $\alpha$ coefficient (Gliem and Gliem, 2003). The Cronbach's $\alpha$ coefficient are presented in Table 3. According to Gliem and Gliem (2003) the minimum acceptable level of Cronbach's $\alpha$ coefficient is 0.7 to indicate the reliability. As can be seen in Table 3 the coefficients for all three constructs are greater than 0.7 , therefore we can verify the reliability of research constructs. In order to verify the validity of the measurements, this study applies average variance extracted (AVE). Calculating the shared variance between two constructs and verifying that it is lower than the average variances extracted for each individual construct are means to assess validity in the measurement model (Shook et al., 2004). In order for the model to satisfy the requirement of validity, the AVE values should be greater that correlations coefficients among the constructs. Comparing the correlation coefficient in Table 1 and AVE values in Table 3, we can see that AVE values are all greater that correlations, therefore we can verify the validity of the measurement in this study. 
Table 3. The constructs' Cronbach's $\alpha$ coefficients and AVEs

\begin{tabular}{lll}
\hline Constructs & Cronbach's $\alpha$ & AVE \\
\hline P2P lending industry & 0.735 & 0.652 \\
\hline SMEs performance & 0.746 & 0.684 \\
\hline Economic indicators & 0.812 & 0.745 \\
\hline
\end{tabular}

\subsection{The Results of the Structural Model}

This section presents the results of hypotheses testing in the structural model as mentioned in Table 4 and Figure 1. The results obtained from the overall fit highlights that the structural model is within the acceptable range. Adding more paths in this research framework would not significantly improve the fit. The residuals of the covariance are also small and centered near 0 . All three paths in the overall model are positive and significant as shown in Figure 1 and Table 4 therefore all three hypotheses are supported. This study can verify that the developments in P2P lending industry has significant and positive impact on the overall economic indicators and also the mediating role of SMEs performance is supported in the model. In line with the data and previous research, it is verified that development of P2P industry in China has a positive and significant impact on the performance of SMEs.

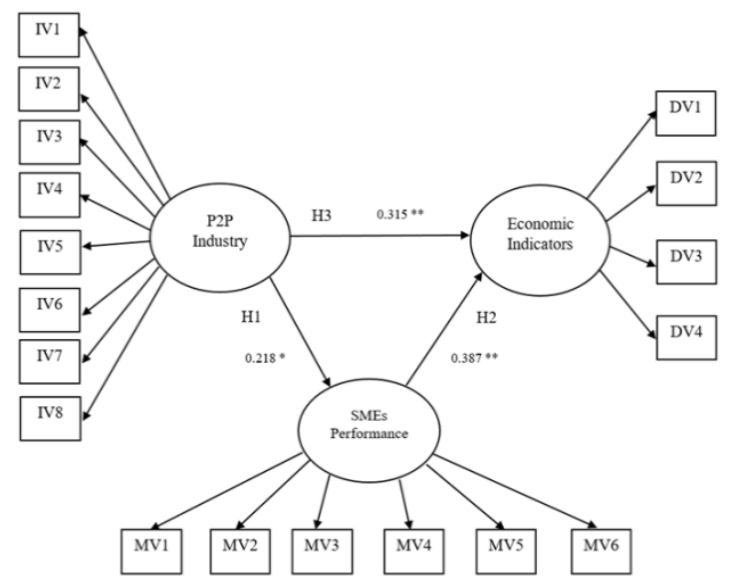

Figure 1. The results of the full model

Note: $* \mathrm{p}<0.05, * * \mathrm{p}<0.01$

Table 4. The results of the structural model

\begin{tabular}{llll}
\hline Hypothesis & Proposed effect & Path coefficient & Results \\
\hline H1 & + & $0.218 *$ & H1 is supported \\
\hline H2 & + & $0.387 * *$ & H2 is supported \\
\hline H3 & + & $0.315 * *$ & H3 is supported \\
\hline$* * 0<0.01$ & &
\end{tabular}

$* p<0.05, * * p<0.01$.

\section{Conclusion}

This study was an attempt to apply SEM to verify the impact of recent developments in the Fintech industry, more particularly P2P industry in China, on the economic factors, in light of mediating impact of SMEs. The empirical results demonstrate that developments in P2P lending industry measured by number of platforms in operation, volume of business turnover, net capital inflow, average duration of loan, number of investors, number of borrowers, 
amount of investment per capita and amount of borrowing per capita has a significant and positive impact on the economic indicators in China measured by annual average inflation rate, urban registered unemployment rate, GDP (Gross Domestic Product) and total tax. The results also indicate the mediating role of SMEs in China as measured by number of SMEs in China, total revenue, net income, total assets, total liabilities and total equity of 100 sample SMEs firms.

This study highlights the importance of considering the role Fintech industry in development of countries more particularly by providing capital and funds to the sections of the society which are deprived from accessing to the conventional financial market due to credit restriction (Mo \& Tan, 2017). In addition, the results can be viewed in light of Transaction Cost Theory for the reluctance of conventional banking and finance industry to provide capital and funds to SMEs and the significance of P2P lending and also other Fintech platforms such as crowdfunding to bridge this gap (Zhao, 2019). However, this does not guarantee the access of all SMEs to sufficient funds and a large number of small and micro enterprises and start-ups still face difficulties to obtain required funds (Ying \& Cai, 2019).

The results of the impact of the performance of Chinese SMEs on China 's national economy have been predicted 15 years ago. As early as 2005, Liu and Wang (2005) believed that apart from state-owned enterprises, SMEs contributed little to the development of the entire national economy in China and their role will be more signified in following years. However, it is worth mentioning that although in recent decade, the economic status of China's SMEs has increased but their proportional contribution to the overall economy is still low (Li, 2018), mainly because most of these enterprises have not received sufficient financial support. In other words, the difficulty of financing has severely restricted the development of Chinese SMEs (Zhang, 2016). The government and financial regulators, should consider the importance of SMEs and provide necessary alternative solutions, such as encouraging and regulating the establishment of low-interest rate, convenient and fast small online loan companies (Ji, 2019).

One of the limitations of present paper is that, the data collected for SMEs performance belong to listed SMEs in Shanghai Stock Exchange only, therefore further research can consider the data for a wider range of SMEs. Future research can add other important constructs into the research framework. Finally, this study hope that the obtained results can be beneficial for government regulators, SMEs and Fintech companies.

\section{References}

Anderson, J. C., \& Gerbing, D. W. (1988). Structural equation modeling in practice: a review and recommended two-step approach. Psychol Bull, 103(3), 411-423. https://doi.org/10.1037/0033-2909.103.3.411

Arner, D. W., Barberis, J., \& Buckley, R. P. (2016). 150 years of Fintech: An evolutionary analysis. Jassa, (3), 22.

Ba, S. (2013). Report on small and micro business financing: Chinese experience and Asian paths. Boao Forum for Asia.

Bailey, W., Huang, W., \& Yang, Z. S. (2011). Bank loans with Chinese characteristics: Some evidence on inside debt in a state-controlled banking system. The Journal of Financial and Quantitative Analysis, 46(6), 1795-1830. https://doi.org/10.1017/S0022109011000433

Bechtti, L., Castelli, A., \& Hasan, I. (2008). Investment-cash flow sensitivities, credit rationing and financing constraints in small and medium-sized firms. Social Science Electronic Publishing, 35(4). https://doi.org/10.1007/s11187-008-9167-1

Bruhn, M., \& Love, I. (2014). The real impact of improved access to finance: Evidence from Mexico. The Journal of Finance, 69(3), 1347-1376. https://doi.org/10.1111/jofi.12091

Chen, L., \& Ye, D. Z. (2016). China P2P network loan interest rate movement research. International Finance Research, 1, 83-96.

Citi Group. (2016). Digital disruption, how FinTech is forcing banking to a tipping point.

Claessens, S., Frost, J., Turner, G., \& Zhu, F. (2018). Fintech credit markets around the world: size, drivers and policy issues. BIS Quarterly Review, September 2018, p.21.

Coase, R. H. (1993). The nature of the firm: origins, evolution, and development. Oxford University Press, USA.

Crosswell, C., \& Estlin, P. (2019). UK FinTech-State of the nation, department for international trade and HM treasury (pp. 1-56).

Dai, J. (2017). Discussion on financing for Small and medium-sized enterprises through P2P online loan model. Journal of Lanzhou Institute of Technology, 24(2), 111-114. 
Degryse, H., \& Van Cayseele, P. (2000). Relationship lending within a bank-based system: Evidence from European small business data. Journal of Financial Intermediation, 9(1), 90-109. https://doi.org/10.1006/jfin.1999.0278

Gliem, J. A., \& Gliem, R. R. (2003). Calculating, interpreting, and reporting Cronbach's alpha reliability coefficient for Likert-type scales. Midwest Research-to-Practice Conference in Adult, Continuing, and Community Education.

Hinson, R., Lensink, R., \& Mueller, A. (2019). Transforming agribusiness in developing countries: SDGs and the role of FinTech, Current Opinion in Environmental Sustainability. Elsevier B.V., 41, 1-9. https://doi.org/10.1016/j.cosust.2019.07.002

Huang, R. H. (2017). Online P2P lending and regulatory responses in China: opportunities and challenges. European Business Organization Law Review, 19(1), 63-92. https://doi.org/10.1007/s40804-018-0100-z

Hung, D. (2019). Foreigners misunderstand China's P2P lending industry. China Banking News.

Ji, H. Ch. (2019). Research on the influencing factors of the development of microcredit companies-based on Henan Province. Finance, 9(01), 41. https://doi.org/10.12677/FIN.2019.91006

Ju, X., Ferreira, F. A., \& Wang, M. (2019). Innovation, agile project management and firm performance in a public sector-dominated economy: Empirical evidence from high-tech small and medium-sized enterprises in China. Socio- Economic Planning Sciences, 100-779. https://doi.org/10.1016/j.seps.2019.100779

Lee, I., \& Shin, Y. J. (2018). Fintech: Ecosystem, business models, investment decisions, and challenges. Business Horizons, 61(1), 35-46. https://doi.org/10.1016/j.bushor.2017.09.003

Li, X. H. (2018). Analysis of the contribution of SMEs to the economy of Liaoning. Modern Business, (24), 33.

Li, Z. (2015). An empirical study on the relationship between P2P network lending and financing of small micro-enterprises in China. Discussion of Modern Economy, 2015(02).

Lin, G., \& Chen, T. (2012). Risk and prevention of establishing private banks in Wenzhou. Journal of Wenzhou Vocational \& Technical College, 12(1), 8-23.

Liu, Q., Zou, L., Yang, X., \& Tang, J. (2019). Survival or die: a survival analysis on peer-topeer lending platforms in China. Acc. Finance, 59, 2105-2131. https://doi.org/10.1111/acfi.12513

Liu, W., \& Wang, L. (2005). Global leadership (1st ed.). Beijing: Tsinghua University Press.

Ma, S., Wu, X., \& Gan, L. (2019). Credit accessibility, institutional deficiency and entrepreneurship in China. China Economic Review, 54, 160-175. https://doi.org/10.1016/j.chieco.2018.10.015

Mamonov, S., \& Malaga, R. (2018). Success factors in Title III equity crowdfunding in the United States, Electronic Commerce Research and Applications. Elsevier B. V., 27, 65-73. https://doi.org/10.1016/j.elerap.2017.12.001

McKinsey and Company. (2014). Perspectives on founder-and family-owned businesses, October. Report of the Top 500 Firms in China.

Mo, Y. X., \& Tan, Zh. H. (2017). P2P online loan platform rating system design flaw analysis. Journal of Shanghai Lixin University of Accounting and Finance, (5), 5.

Moreno, A. M. (2019). Success factors in Peer-to-Business (P2B) crowdlending: a predictive approach. IEEE Access, 7, 148586-148593. https://doi.org/10.1109/ACCESS.2019.2946858

Prospective Industry Research Institute (PIRI). (2019). Analysis of China's FinTech industry market status and development trend in 2019. Economic Information Daily.

PWC. (2017). Global FinTech Survey China Summary 2017 (pp. 5-11). PWC China.

Rosavina, M., Rahadi, R. A., Kitri, M. L., Nuraeni, S., \& Mayangsari, L. (2019). P2P lending adoption by SMEs in Indonesia. Qualitative Research in Financial Markets, 11(2), 260-279. https://doi.org/10.1108/QRFM-09-2018-0103

Shim, Y., \& Shin, D. H. (2016). Analyzing China's fintech industry from the perspective of actor-network theory. Telecommunications Policy. Elsevier, 40(2-3), 168-181. https://doi.org/10.1016/j.telpol.2015.11.005

Shook, C. L., Ketchen, Jr, D. J., Hult, G. T. M., \& Kacmar, K. M. (2004). An assessment of the use of structural equation modeling in strategic management research. Strategic Management Journal, 25(4), 397-404. https://doi.org/10.1002/smj.385 
Suryono, R. R., Purwandari, B., \& Budi, I. (2019). Peer to Peer (P2P) Lending problems and potential solutions: A systematic literature review, procedia computer science. Elsevier B.V., 161, 204-214. https://doi.org/10.1016/j.procs.2019.11.116

Susilo, A. Z., et al.. (2019). A comparative study of factors affecting user acceptance of GO-PAY and OVO as a feature of Fintech application, Procedia Computer Science. Elsevier B.V., 161, 876-884. https://doi.org/10.1016/j.procs.2019.11.195

Tanaka, K., \& Molnar, M. (2008). What is different about informal finance? Financing of private firms in China. Revue Economique, 59(6), 1131-1143. https://doi.org/10.3917/reco.596.1131

Tavakol, M., \& Dennick, R. (2011). Making Sense of Cronbach's Alpha. International Journal of Medical Education, 2011(2), 53-55. https://doi.org/10.5116/ijme.4dfb.8dfd

Wang, H. J., \& Liao, L. (2014). Research on the credit certification mechanism of P2P network loan platform in China. China Industrial Economics Press, 2014(31304), 136-147.

Wang, J. (2020). Why are the P2P online loans in 2019 sad?. China Finance, (11-1267/F).

Wang, X. (2018). On the impact of the development of internet finance on the financing of small and medium-sized enterprises. Business Intelligence (Shang Qing), 36(1673-4041), 36.

WDZJ. (2019). 2019 China P2P lending industry annual report. P2P Lending Report. Shanghai: Shanghai Yingxun Technology Ltd., 8-28.

Welltrado. (2018). Global Blockchain-Backed Loans Marketplace ICO. White Paper March.

World Bank. (2013). Enterprise surveys: China.

Xu, G. (2019). China's P2P lending market could be decimated this year amid Beijing crackdown. South China Morning Post.

Xue, H., \& Shui, J. (2015). Discussion on P2P financing model for small and medium-sized enterprises in the age of Internet finance. Business Accounting, 2015(3), 29-31.

Yang, Z. (2019). Exploring the difficulty of financing small and medium-sized enterprises in China. National Circulation Economy, 31(2096-3157), 81-83.

Ying, Sh. P., \& Cai, H. Q. (2019). Difficulties and measures for SME financing. Modern Enterprises, (10), 51.

Yu, L., \& Xie, C. (2014). Relationship loans, group loan technology and the boundaries of financial system research and the latest progress of SME loan difficulty. Journal of Theory, 10(1002-3909), 70-77.

Zhang, J. (2002). Relationship lending to small and medium enterprises and the organizational structure of banks. Economic Research, 6.

Zhang, K. (2016). Analysis of China's SMEs' financing environment. Cooperative Economy and Technology, (6), 44-45.

Zhang, X.-C., Xu, Z., \& Qin, D. (2013). The outlet of folk lending interest rates and folk capital: The case of Wenzhou. Journal of Financial Research, 393, 1-14.

Zhao, Ch. G. (2019). Research on P2P corporate governance of online loan platform from the perspective of financial ecology. Finance and Accounting, 817(17), 45-48.

Zhao, Y. (2014). P2P Network Lending to Ease financing difficulties for technology-based SMEs. Economic Research Reference, 25(2095-3151), 57-64.

\section{Copyrights}

Copyright for this article is retained by the author(s), with first publication rights granted to the journal.

This is an open-access article distributed under the terms and conditions of the Creative Commons Attribution license (http://creativecommons.org/licenses/by/4.0/). 